\title{
School Organizational Climate and Job Satisfaction of MSU Junior High School Teachers
}

\author{
Anabelie V. Valdez ${ }^{1}$, Analyn P. Guro ${ }^{2}$, Norhana H. Cana ${ }^{3}$, Lawan M. Lawi ${ }^{4}$ \\ Mindanao State University (MSU), External Studies
}

\begin{abstract}
This study examines the relationship of the teachers' profile, to the school organizational climate and job satisfaction of the teachers. Using descriptive correlational design, the investigation was participated by 30 junior high schools that were purposively selected through convenient sampling. The results of the statistical analysis revealed that teacher profile such as age, marital status, educational attainment and teaching experience are having positive and significant relation to organizational climate and job satisfaction. Likewise, organizational climate and job satisfaction are also significantly correlated and have directly proportional relationships. As such, organizational leaders, employees/teachers profile has significant bearing in promoting favorable organizational climate while organizational climate has significant contributions in promoting the job satisfaction of the workers.
\end{abstract}

Keywords: teachers, school organizational climate, job satisfaction

\section{Introduction}

Each organization has organizational climate which mostly influence by the personality of a person. According to McLaughlin (2017), organizational climate has many different types and can be group in varied ways. He said that the climate of an organization could be people oriented, rule-oriented, innovation-oriented or goal-oriented. Organizational climate contributes the success of an organization and job satisfaction of its employees. Organizational climate includes the structures and behavior of leaders and employees.

Organizational climate has direct link to job satisfaction. Employees who have inspiring working environment, more competitive compensation are productive and satisfied with their job. Gupta (2008) said that more encouraging organizational climate develops prospective and proficient employees. To do this, the organizational leaders should be responsible in building positive and motivate their employees. Leaders believed that when the employees are satisfied with their working environment their performance is at higher level and more committed to do their work. Furthermore, the existence of open communication, management recognition of employees, giving rewards and benefits are most important factors to consider in an organization. Employees will be fully engaged to their work and contented with their job if they are gratified with their working environment (People Insight, 2016).

Research conducted by Kumar and Giri (2007) andLok et.al. (2017) stressed out that organizational climate and job satisfaction plays vital role towards organization success. Issues about organizational climate continue to cause employees job dissatisfaction.

In connection to the aforementioned issues and studies about organizational climate and job satisfaction, this study aimed to investigate the extent relation of organizational climate and job satisfaction among junior high school teachers in Mindanao State University Community High Schools specifically investigating on:

1. Personal profile of the respondents

2. Respondents perceptions of their organizational school climate

3. Respondents satisfaction with their working environment

4. Respondents self-evaluation on their job satisfaction and; 
5. Relationship between personal profile, organizational school climate and job satisfaction as perceived by the respondents

\section{Methods}

\section{A. Research Design}

This study utilized the descriptive-correlational research design as it tries to find out the type of relationship between respondents profile, organizational climate and job satisfaction, using survey questionnaires.

\section{B. Research Local and Respondents}

Research locale of the study was confined only in the MSU External High Schools who participated voluntarily the survey at their own convenient. The 30 junior high school serves as the respondents of the study. Convenient sampling was employed in getting the number of respondents.

\section{Research Instruments}

The research instruments used in the study were categorized into three sub-topics. Sub-topic 1 is the personal profile of the respondents, sub-topic 2 is the organizational climate survey and the sub-topic 3 is the job satisfaction survey. The organizational climate and job satisfaction survey was patterned from research instruments used by other researchers who conducted similar study which was modified and validated by the researchers in this study.

D. Data Analysis

The data obtained from the respondents was quantitatively analyze using frequency, percentage weighted mean, and Pearson product of correlation.

\section{Results and Discussions}

\section{A. Respondents Profile}

Table 1 Respondents Profile

\begin{tabular}{|c|c|r|}
\hline \multicolumn{2}{|l|}{ Personal Profile } & \\
\hline Age & F & $\%$ \\
\hline 25 below & 2 & 6.67 \\
\hline $26-35$ & 14 & 13.3 \\
\hline $36-45$ & 4 & 33.3 \\
\hline 46 above & 10 & \\
\hline Male & 5 & 16.7 \\
\hline Female & 25 & 83.3 \\
\hline Single & 9 & 30 \\
\hline Married & 21 & 70 \\
\hline Qualifications & & 36.7 \\
\hline diploma & 11 & 6.67 \\
\hline graduate & 2 & 56.7 \\
\hline
\end{tabular}




\begin{tabular}{|c|c|r|}
\hline Experience & & \\
\hline $0-10 \mathrm{yrs}$ & 17 & 56.7 \\
\hline $11-20 \mathrm{yrs}$ & 2 & 6.67 \\
\hline $21-30 \mathrm{yrs}$ & 3 & 10 \\
\hline 31 above & 8 & 26.7 \\
\hline
\end{tabular}

Table 1 show the respondents' teachers' profile. As shown, many (47\%) teachers are young ones, female $(83 \%)$, married $(70 \%)$, graduate $(57 \%)$, and have $0-10$ years $(57 \%)$ of teaching experience.

\section{B. School Organizational Climate}

Table 2 Teachers Personal View of their School Organizational Climate

\begin{tabular}{|c|c|c|c|}
\hline & Statement & Yes & No \\
\hline 1 & Do you always receive the information that is needed to do your job? & 20 & 10 \\
\hline 2 & $\begin{array}{l}\text { Do you believe that you will have career growth opportunities in this } \\
\text { company? }\end{array}$ & 23 & 7 \\
\hline 3 & $\begin{array}{l}\text { Are you encouraged to contribute to the improvement of work } \\
\text { processes? }\end{array}$ & 25 & 5 \\
\hline 4 & Are you always learning new things in your job? & 26 & 4 \\
\hline 5 & $\begin{array}{l}\text { Does clarification and guidance from your superiors regarding your } \\
\text { tasks help to carry out your work? }\end{array}$ & 22 & 8 \\
\hline 6 & Do your superiors help you to figure out how to learn and train? & 21 & 9 \\
\hline 7 & Does the company provide training opportunities for everyone? & 17 & 13 \\
\hline 8 & $\begin{array}{l}\text { Do you have a career outlook that motivates you to work for this } \\
\text { company? }\end{array}$ & 26 & 4 \\
\hline 9 & $\begin{array}{l}\text { Does the organization's environment facilitate the relationship } \\
\text { between employees? }\end{array}$ & 16 & 14 \\
\hline 10 & Are your colleagues always willing to help each another? & 25 & 5 \\
\hline 11 & Do you trust your co-workers? & 21 & 9 \\
\hline 12 & $\begin{array}{l}\text { Do the employees of this company have a good relationship with } \\
\text { each other? }\end{array}$ & 14 & 16 \\
\hline 13 & Do other employees come promptly when you need their help? & 20 & 10 \\
\hline 14 & In general, do your colleagues share knowledge? & 24 & 6 \\
\hline 15 & Are all employees involved in decision making? & 11 & 19 \\
\hline 16 & $\begin{array}{l}\text { Do you believe that the time you use in your work day is sufficient to } \\
\text { fulfil your duties and obligations? }\end{array}$ & 29 & 1 \\
\hline 17 & Do you wish you had more senior responsibilities? & 17 & 13 \\
\hline 18 & Are you happy in your work? & 27 & 3 \\
\hline 19 & $\begin{array}{l}\text { Do you consider that your work is important for the company to } \\
\text { reach its goals? }\end{array}$ & 29 & 1 \\
\hline 20 & $\begin{array}{l}\text { Do you feel that working in this company contributes to improving } \\
\text { your life? }\end{array}$ & 28 & 2 \\
\hline 21 & $\begin{array}{l}\text { Do you believe that your work in the company provides you and your } \\
\text { family with security? }\end{array}$ & 29 & 1 \\
\hline 22 & $\begin{array}{l}\text { Are you proud of this company? Do you have friends and relatives } \\
\text { working here? }\end{array}$ & 23 & 7 \\
\hline
\end{tabular}




\begin{tabular}{|c|c|c|c|}
\hline 23 & $\begin{array}{l}\text { When you have finished your day and go home, do you feel fulfilled } \\
\text { professionally? }\end{array}$ & 24 & 6 \\
\hline 24 & Do you know the objectives of this company? & 27 & 3 \\
\hline 25 & $\begin{array}{l}\text { Do you believe that the products and services offered to the market } \\
\text { by this company are important to society? }\end{array}$ & 28 & 2 \\
\hline & $\begin{array}{ll} & \text { mean }\end{array}$ & 22.88 & 7.12 \\
\hline
\end{tabular}

Table 2 presents teachers personal views about their school organizational climate. As shown in the table majority of them shown favorable opinion to their school organizational climate. The "yes" response garnered a mean of 22.88 versus the "no" response that is only 7.12. This finding implies that the teachers' respondents love their working environment and has good relationships to their school principal, peers and students as well.

\section{Satisfaction with the School Organizational Climate}

Figure 1 below shows the response of the teachers with regards to their satisfaction to their school organizational climate.

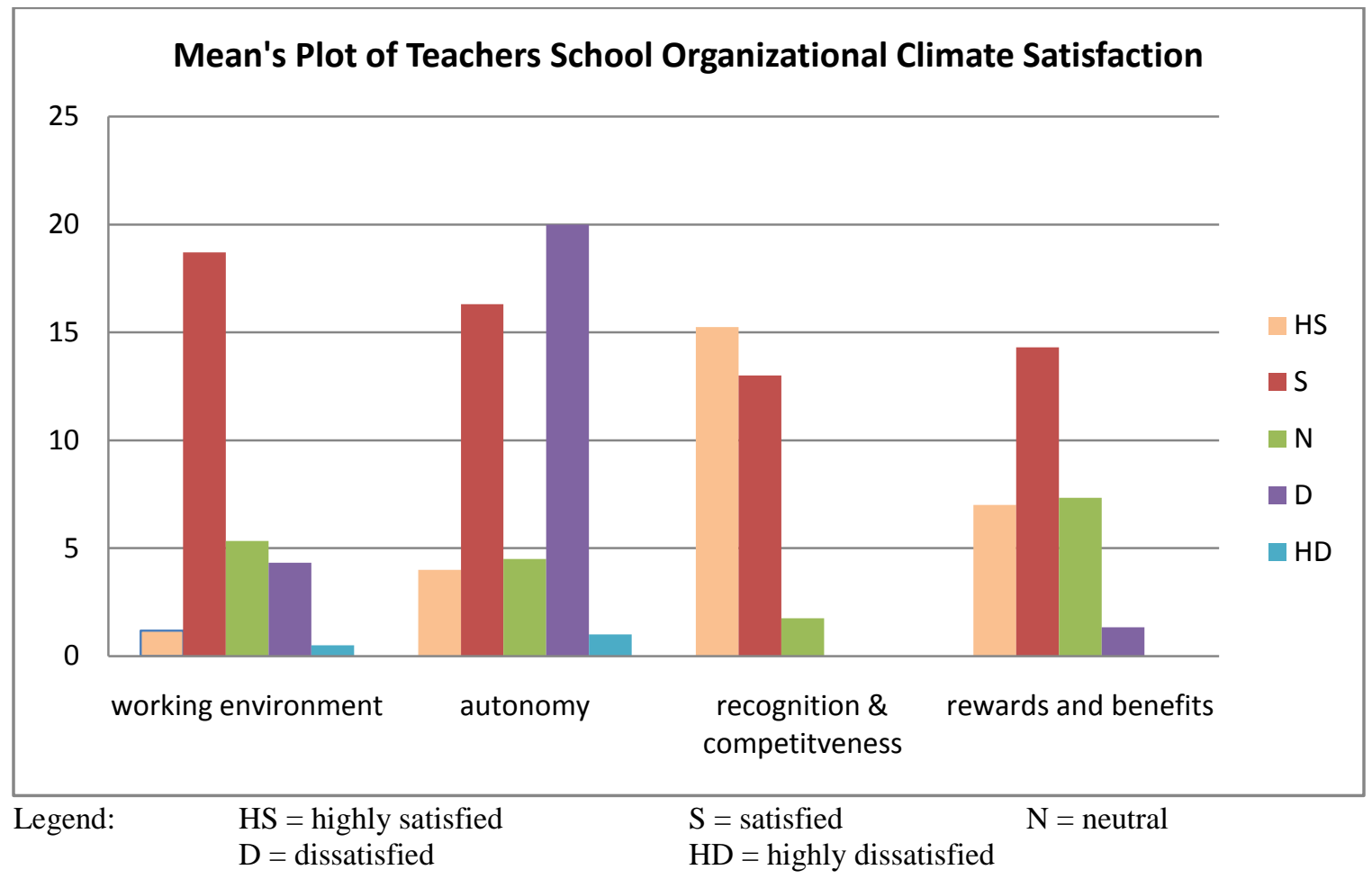

As revealed in the figure, the teachers are satisfied to their working environment and in the rewards and benefits. Moreover, they are highly satisfied to the recognition and competitiveness given to them. However, they feel dissatisfied in terms of their autonomy in school. Maybe, they are closely supervised and monitored by their school principal and immediate supervisor. According to the teachers they usually have benevolent relationship with their immediate supervisor, but sometimes strictness also exists. In the school they are free to communicate with each other, free to express views and suggestions particularly in decision making process but their views and opinions are sometimes considered only. It is very imperative that employees/teachers is involve in seeking solutions by giving them chance to talk and make propositions and suggestions (People Insight, 2016).

According to the study of Gonz'alez-Rom'a et al. (2002) the deeper the communication is the better the organizational climate. Others also believed that a more consistent and symbiotic organization promote an 
encouraging and motivating organizational climate (Zohar \&Tenne-Gazit 2008; Luria 2008). This means that to promote good organizational climate in any organization there should be more interdependent, open communication, more interaction, and clear strategic vision for the job or work.

\section{Job Satisfaction}

Table 3 Teachers Perceptions about their Job

\begin{tabular}{|c|c|c|c|}
\hline & Statements & Yes & No \\
\hline 1 & Do you enjoy your school's culture? & 22 & 8 \\
\hline 2 & Do you find your work meaningful? & 30 & 0 \\
\hline 3 & $\begin{array}{l}\text { Do your school offer chances for professional growth and } \\
\text { promotion? }\end{array}$ & 22 & 8 \\
\hline 4 & Do you feel valued for your contributions? & 20 & 10 \\
\hline 5 & $\begin{array}{l}\text { Does your school provide instructional materials and facilities } \\
\text { needed for your teaching? }\end{array}$ & 11 & 19 \\
\hline 6 & Do your supervisor and principal transparent in communication? & 16 & 14 \\
\hline 7 & $\begin{array}{l}\text { Do you informed with your other responsibilities aside from } \\
\text { teaching? }\end{array}$ & 25 & 5 \\
\hline 8 & $\begin{array}{l}\text { Do you think that time management and distribution in teaching } \\
\text { loads are balance? }\end{array}$ & 13 & 17 \\
\hline 9 & Do you feel connected to your co-workers? & 26 & 4 \\
\hline 10 & Do you feel your significance in the school? & 27 & 3 \\
\hline 11 & $\begin{array}{l}\text { Do the school heads and management promote unity and } \\
\text { camaraderie? }\end{array}$ & 18 & 12 \\
\hline 12 & Do your managers value your feedback? & 12 & 18 \\
\hline & mean & 20.17 & 9.83 \\
\hline
\end{tabular}

Teachers' perception about their job is shown in Table 3. As revealed in the table most of them are happy and contented to their job considering that the "yes" response has a mean of 20.17 compared to the "no response which has a mean of 9.83 only.

However, in Table 4 when they were asked on degree of agreement and disagreement of the twelve (12) statement given they tend to disagree on statement number 6 stating that "There is good communication from principal to teachers" and nine (9) of them are undecided on the statement of being underutilized to their job. Nevertheless, majority of the teachers views are in favor of being satisfied to their job and have a positive outlook in working in the school. Many (23) of them believed that they have a clear path for career and advancement through study leave, trainings and other professional growth for the teachers. The also affirmed that the workload given to them is reasonable and that their job requirements are clear to them.

Table 4 Teachers Views on their Job with Respect to their School Environment

\begin{tabular}{|c|c|c|c|c|c|c|}
\hline \multirow{2}{*}{\multicolumn{2}{|c|}{ Statement }} & \multicolumn{5}{|c|}{ Response } \\
\hline & & SD & $\mathrm{D}$ & $\mathrm{N}$ & $A$ & $\mathrm{SA}$ \\
\hline 1 & The school clearly communicates its goals and strategies to me. & 3 & 5 & 3 & 14 & 5 \\
\hline 2 & $\begin{array}{l}\text { My principal recognizes my skills and gives me opportunities to } \\
\text { share my skills to my co-teachers in the system. }\end{array}$ & 3 & 4 & 7 & 14 & 2 \\
\hline
\end{tabular}

(c) 2019, IJSMS

Page 96 


\begin{tabular}{|c|c|c|c|c|c|c|}
\hline 3 & $\begin{array}{l}\text { My career advancement is clear and program with approval by my } \\
\text { school principal }\end{array}$ & 1 & 1 & 2 & 23 & 3 \\
\hline 4 & My job requirements are clear. & 2 & 1 & 1 & 19 & 7 \\
\hline 5 & The company clearly conveys its mission to its employees. & 1 & 3 & 6 & 17 & 3 \\
\hline 6 & There is good communication from principal to teachers. & 2 & 10 & 8 & 9 & 1 \\
\hline 7 & I have the tools and resources I need to do my job. & 2 & 5 & 3 & 18 & 2 \\
\hline 8 & I have the training I need to do my job & 2 & 4 & 3 & 18 & 3 \\
\hline 9 & I feel underutilized in my job. & 2 & 8 & 9 & 8 & 3 \\
\hline 10 & The amount of work expected of me is reasonable. & 0 & 3 & 3 & 20 & 4 \\
\hline 11 & It is easy to get along with my colleagues. & 0 & 4 & 5 & 17 & 4 \\
\hline 12 & The morale in my department is high & 0 & 5 & 4 & 15 & 4 \\
\hline & mean & 1.5 & 4.47 & 4.5 & 16 & 3.47 \\
\hline
\end{tabular}

E. Relationship between respondents profile, organizational climate and job satisfaction Profile and Organizational Climate

Table 5 Respondents Profile and Organizational Climate

\begin{tabular}{|l|l|r|r|r|r|r|}
\hline \multicolumn{2}{|l|}{} & \multicolumn{6}{c|}{ Respondents Profile } \\
\hline \multicolumn{2}{|l|}{ Organizational Climate } & age & \multicolumn{1}{c|}{ sex } & \multicolumn{1}{c|}{$\begin{array}{c}\text { Marital } \\
\text { status }\end{array}$} & $\begin{array}{c}\text { Educational } \\
\text { attainment }\end{array}$ & \multicolumn{1}{c|}{$\begin{array}{c}\text { Teaching } \\
\text { experience }\end{array}$} \\
\hline $\begin{array}{l}\text { Teachers } \\
\text { Personal Views }\end{array}$ & $\begin{array}{l}\text { Pearson } \\
\text { Correlation }\end{array}$ & $.700^{* *}$ & .247 & $.361^{*}$ & $.467^{* *}$ & $.811^{* *}$ \\
\cline { 2 - 7 } & Sig. (2-tailed) & .000 & .189 & .050 & .009 & .000 \\
\hline $\begin{array}{l}\text { Teachers } \\
\text { Satisfaction }\end{array}$ & $\begin{array}{l}\text { Pearson } \\
\text { Correlation }\end{array}$ & $.837^{* *}$ & $.588^{* *}$ & $.634^{* *}$ & $.673^{* *}$ & $.854^{* *}$ \\
\cline { 2 - 7 } & Sig. (2-tailed) & .000 & .001 & .000 & .000 & .000 \\
\cline { 2 - 7 } & $\mathrm{N}$ & 30 & 30 & 30 & 30 & 30 \\
\hline
\end{tabular}

Findings presented in Table 5 revealed that organizational climate is positively associated with the respondents profile such us the age, sex, marital status, educational attainment and teaching experience of the teachers. Base on this finding, it affirms that organizational climate will matter with respect to the personal profile of the employees or teachers.

Study conducted by Liao \& Chuang (2007) and Walumbwa et al. (2010) pointed out that leadership is very important in organizational climate. Similarly, leader's personal profile and characteristics are very important in any organization as well (Salvaggio et. al, 2007). The quality of the organizational head and employees has significant contribution in promoting good organizational climate that lead to their efficient working performance (Chuang \& Liao, 2010)

Research findings of Jyotil (2013) revealed that educational level and experiences has significant effects on organizational climate. Leaders and employees/teachers who had high educational attainment and experience have more positive perceptions in developing good and conducive organizational climate.

However, in terms of teachers' job satisfaction and their personal profile Table 6 revealed that sex does not matter when talking about job satisfaction. This means that employees or a teacher has the same feeling in terms of job satisfaction regardless of their sex. Yet, job satisfaction will matter in terms of age, marital status, educational attainment and teaching experience. 
Table 6 Respondents Profile and Job Satisfaction

\begin{tabular}{|l|l|r|r|r|r|r|}
\hline \multicolumn{2}{|c|}{} & \multicolumn{6}{|c|}{ Respondents Profile } \\
\hline Job Satisfaction & age & \multicolumn{1}{|c|}{ sex } & $\begin{array}{c}\text { Marital } \\
\text { status }\end{array}$ & $\begin{array}{c}\text { Educational } \\
\text { attainment }\end{array}$ & $\begin{array}{c}\text { Teaching } \\
\text { experience }\end{array}$ \\
\hline $\begin{array}{l}\text { Teachers } \\
\text { Perception }\end{array}$ & Pearson Correlation & $.831^{* *}$ & .293 & $.429^{*}$ & $.554^{* *}$ & $.907^{* *}$ \\
\cline { 2 - 7 } & Sig. (2-tailed) & .000 & .116 & .018 & .001 & .000 \\
\hline $\begin{array}{l}\text { Teachers job } \\
\text { satisfaction as to } \\
\text { school } \\
\text { environment }\end{array}$ & Pearson Correlation & $.751^{* *}$ & $.790^{* *}$ & $.840^{* * *}$ & $.841^{* * *}$ & $.626^{* * *}$ \\
\cline { 2 - 7 } & Sig. (2-tailed) & .000 & .000 & .000 & .000 & .000 \\
\cline { 2 - 7 } & $\mathrm{N}$ & 30 & 30 & 30 & 30 & 30 \\
\hline
\end{tabular}

In Table 7, data revealed that organizational climate has positive and significant effect or influence job satisfaction of the employees or teachers. This finding implies that job satisfaction of the employees or teachers for this matter are influence by the nature of their working environment or organizational climate.

Table 7Organizational Climate and Job Satisfaction

\begin{tabular}{|c|c|c|c|}
\hline \multirow[b]{2}{*}{ Job Satisfaction } & & \multicolumn{2}{|c|}{ Organizational Climate } \\
\hline & & $\begin{array}{c}\text { Teachers } \\
\text { Personal } \\
\text { Views }\end{array}$ & $\begin{array}{c}\text { Teachers } \\
\text { Satisfaction }\end{array}$ \\
\hline \multirow{3}{*}{ Teachers Perception } & Pearson Correlation & $.875^{* *}$ & $.843^{* * *}$ \\
\hline & Sig. (2-tailed) & .000 & .000 \\
\hline & $\mathrm{N}$ & 30 & 30 \\
\hline \multirow{3}{*}{$\begin{array}{l}\text { Teachers job satisfaction } \\
\text { as to school environment }\end{array}$} & Pearson Correlation & $.795^{* *}$ & $.502^{* *}$ \\
\hline & Sig. (2-tailed) & .000 & .005 \\
\hline & $\mathrm{N}$ & 30 & 30 \\
\hline
\end{tabular}

Jyotil (2013) concluded in his research that organizational climate and job satisfaction are vital in holding efficient employees/teachers and the same time enhances their commitment to their work. In wider perspective, environment where employees are satisfied with their job can fully engage their work and encouraging organizational climate promote the organization ability to attract, retain and develop the employees/teachers skills and talents (People Insight, 2016).

Working environment as regards to organizational climate and employees/teachers working experiences is difficult to assess but it directs their daily lives. Thus, organizational climate is also affected by other factors which include the organizational culture (Schneider, B.; Ehrhart, M.G.; and Macey, W.H. (2013).

\section{Conclusion and Recommendation}

Base on the purpose of the study that to evaluate the extent relationship of organizational climate job satisfaction and teachers profile, the study concluded that personal profile of the teachers/employees such as age, educational attainment, marital status and teaching/working experience plays significant contribution in developing good organizational climate. Moreover, they said profile has positive and significant relationship also to the job satisfaction. Similarly, organizational climate is tangible in the job satisfaction of employees. Therefore, when organizational climate and working environment is conducive and favorable to the workers, then they tend to be satisfied with their job. Thus, it is very important to note that organizational leaders must be sensitive and vigilant with the existing organizational climate in their organization. They must be a game player that motivate and enhance the employees to be more productive and happy to their work and environment. 


\section{References}

[1] Chuang C-H, Liao H. 2010. Strategic human resource management in service context: taking care of business by taking care of employees and customers. Pers. Psychol. 63:153-96

[2] Gonz'alez-Rom'a V, Peiro JM, Tordera N. 2002. An examination of the antecedents and moderator influences of climate strength. J. Appl. Psychol. 87:465-73

[3] Gupta, A. (2008). Organizational Climate Study. Organizational Traineeship Segment PRM 28055

[4] Jyoti, J. (2013). Impact of Organizational Climate on Job Satisfaction, Job Commitment and Intention to Leave: An Empirical Model. Commerce Department, University of Jammu, Jammu

[5] Kumar, B. P., \&Giri, V. N. (2007), Organizational Commitment, Climate and Job satisfaction: An Empirical Study.The ICFAI journal of Organizational Behaviour, 6(3), 7-18.

[6] Liao H, Chuang A. 2007. Transforming service employees and climate: a multilevel multi-source examination of transformational leadership in building long-term service relationships. J. Appl. Psychol. 92:1006-19

[7] Lok, P., Paul, Z. W., Bob W., \& John C. (2007). Antecedents of job satisfaction and organizational commitment and the mediating role of organizational subculture. Retrieved fromhttp://www.unisa.edu.au/igsb/docs/WP-Lok2.pdf

[8] Luria G. 2008. Climate strength—how leaders form consensus. Leadersh. Q. 19:42-53

[9] McLaughlin, J. (2017). Organizational Behavior: Help and Review @ copyright 2003-2017 Study.com. All other trademarks and copyrights are the property of their respective owners. All rights reserved.

[10] People Insight (July 2016)• Southern Nevada Health District Employee Job Satisfaction and Engagement Survey Report: People Insight: Employee Job Satisfaction and Engagement Survey Report 2

[11] Salvaggio AN, Schneider B, Nishii LH,Mayer DM, Ramesh A, Lyon J S. 2007. Manager personality, manager service quality orientation, and service climate: test of a model. J. Appl. Psychol. 92:1741-50

[12] Schneider, B.; Ehrhart, M.G.; and Macey, W.H. (2013). Organizational Climate and Culture by Annual Reviews. All rights reserved1CEB Valtera, Rolling Meadows, Illinois 60008, Department of Psychology, San Diego. State University, San Diego, California 92182

[13] Walumbwa FO, Hartnell CA, Oke A. 2010. Servant leadership, procedural justice climate, service climate, employee attitudes, and organizational citizenship behavior: a cross-level investigation. J. Appl. Psychol.95:517-29

[14] Zohar D, Tenne-Gazit O. 2008. Transformational leadership and group interaction as climate antecedents: a social network analysis. J. Appl. Psychol. 93:744-57 